\title{
GEOGRAFSKI INFORMACIJSKI SISTEMI V REGIONALNI GEOGRAFIJI IN GEOEKOLOGIJI
}

\author{
Drago Perko
}

Izvleček

UDK 913:681.3

Prispevek prikazuje pomembno vlogo geografskih informacijskih sistemov $v$ regionalni geografiji in geoekologiji in nekatere konkretne primere njihove uporabe.

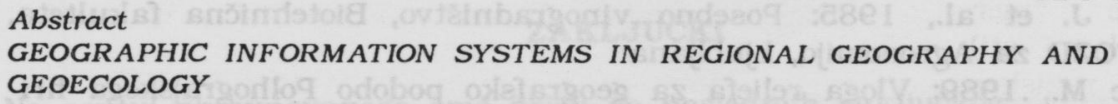

The paper presents an important role of geographic information systems in regional geography and geoecology and also some concrete cases of theirs use.

Pokrajina, ki je temeljni predmet geografske znanosti, je sestavljena iz pokrajinskih sestavin (npr. relief, kamnine, vode, prsti, rastje, prebivalstvo, naselja...), te pa iz pokrajinskih prvin (npr. relief sestavljajo nadmorska višina, naklon, razčlenjenost itd.). Pozornost geografov pa ni usmerjena na proučevanje posameznih sestavin in prvin, ampak predvsem na proučevanje odnosov (razmerij) med njimi, torej na proučevanje povezanosti, odvisnosti, vplivov, soodvisnosti. Geografija torej proučuje odnose med naravnimi in družbenimi sestavinami pokrajine, same sestavine pokrajine, ki jih proučuje cela vrsta sorodnih znanosti, pa so predmet geografije le toliko, kolikor je to potrebno za razumevanje teh odnosov.

Osnovni način dela pri odkrivanju teh odnosov, ki jih lahko imenujemo pokrajinski odnosi, je bila tako imenovana metoda prekrivanja zemljevidov, ki pa je zelo zamudna, ima celo vrsto pomanjkljivosti, hkrati pa večkrat ne da željenih rezultatov. Zato je geografski informacijski sistem za geografijo izjemno pomemben, saj nam metodo ročnega prekrivanja zemljevidov v GIS-u pod našim nadzorom opravi računalnik. Geografu najbolj preprosto in nazorno predstavimo GIS kot računalniško zbirko zemljevidov, ki jih lahko med sabo poljubno prekrivamo in med njimi izvajamo računske in druge operacije, hkrati pa se na točke, linije in poligone ne teh zemljevidih, torej na pojave $v$ pokrajini, navezujejo najrazličnejše baze podatkov, med katerimi prav tako lahko izvajamo različne opracije,

Mag. Drago Perko, Geografski inštitut Antona Melika ZRC SAZU, Gosposka 13, Ljubljana 
oblikujemo nove zemljevide in nove baze podatkov, hkrati s tem pa ugotavljamo zveze med pokrajinskimi pojavi in tako določamo pokrajinske odnose. Prav razlike med pokrajinskimi odnosi pa oblikujejo različne pokrajine.

Ker geografe pri večini raziskav, posebno pri proučevanju večjih regij in pri ugotavljanju splošnih zakonitosti geodetska natančnost zanima le redko, se je $\mathrm{v}$ geografiji kljub nekaterim slabostim, vendar tudi prednostim, bolj uveljavil rastrski GIS, vektorki GIS pa se uporablja le redko.

$\mathrm{Na}$ Geografskem inštitutu Antona Melika Znanstvenoraziskovalnega centra SAZU uporabljamo GIS predvsem pri regionalnogeografskih in pri geoekoloških proučevanjih Slovenije in njenih pokrajin. Pri proučevanju pokrajinskih odnosov pa sta na prvem mestu relief (1991 a, b in c), ki je najpomembnejša in hkrati sorazmerno neodvisna naravna sestavina večine slovenskih pokrajin, in prebivalstvo, ki s svojimi dejavnostmi aktivno posega $v$ pokrajino in spreminja pokrajinske odnose.

Regionalnogeografske raziskave približno enakovredno upoštevajo naravne in družbene sestavine pokrajine, geoekološke pa predvsem naravne, vendar $\mathrm{v}$ končnem odnosu do družbenih: vpliv naravnih razmer na družbene razmere in občutljivost, ranljivost naravnih razmer zaradi delovanja (aktivnosti) družbe.

Pri raziskavah trenutno uporabljamo računalniški paket IDRISI, ki so ga predvsem za potrebe geoekoloških in regionalnih raziskav razvili $v$ ZDA, na oddelku za geografijo na Clark University $v$ Worcestru, pripravljamo pa se na nabavo zmoglivejšega GIS-a. Paket je namenjen za delo $z$ IBM in združljivimi računalniki. Njegove sposobnosti so podobne večjim sistemom (ARCINFO), žal pa ne omogoča dela $z$ razširjenim spominom in smo tako vezani le na osnovnih $640 \mathrm{~Kb}$ spomina. Ima pa več dobrih lastnosti: izjemno nizko ceno (200 do 400 USD), enostavno uporabo (kar je šibka točka večine ostalih GIS-ov), združljivost $z$ nekaterimi drugimi GIS-i in mnogimi grafičnimi in podatkovnimi programi, kratka in razumljiva navodila, kratko dobo učenja (dva do trije tedni) in drugo. Sestavljen je iz več modulov, med drugimi tudi za prostorske statistike, obdelavo satelitskih posnetkov, rasterske slike, vektorske slike itd. (Clark University 1991).

GIS uporabljamo na treh ravneh raziskovanja: na makro ravni predstavlja osnovni sloj generalizirana verzija DMR-ja 100 oziroma DMR 500 ali DMR 1000, osnova za prebivalstvene podatke pa so naselja, na srednji ravni je osnovni sloj DMR 100 in osnova za prebivalstvene podatke podatkovna zbirka Evidenca hiš, na mikro ravni pa je osnovni sloj še bolj natančen DMR (na primer DMR 10).

Najpomembnejše dolgoročne regionalne in geoekološke raziskave inštituta, pri katerih ob ostalih znanstvenih orodjih, tehnikah in metodah aktivno uporabljamo tudi GIS so:

- geoekološka ranljivost Slovenije,

- geoekološke enote Slovenije,

- geoekologija (ostankov) ledenikov Slovenije,

- geoekologija poplavnih pokrajin v Sloveniji,

- geoekologija poseljenosti Slovenije,

- geoekologija gorskih kmetij v Sloveniji,

- geoekologija naravnih nesreč v Sloveniji, 
- regionalna monografija Slovenije,

- regionalni in geoekološki sistemi v Sloveniji.

V referatu na kratko predstavljamo nekaj spoznanj iz treh različnih raziskav, ki spadajo $\mathrm{v}$ omenjene sklope raziskav.

\section{GEOEKOLOGIJA ARBORETUMA VOLČJI POTOK}

Proučevanje spada med mikrogeoekološke raziskave. Obdelali smo območje pravokotne oblike velikosti 1500 krat $1500 \mathrm{~m}$ oziroma $2,25 \mathrm{~km}^{2}$ in znotraj njega še posebej območje arboretuma $v$ mejah novega osnutka odloka, ki ima obliko nepravilnega poligona s površino 8252 arov.

Reliefni sloj, ki je najvažnejši in ga zato tudi predstavljamo, smo v GIS vnesli s pomočjo digitalizacije izohips na osnovni topografski karti v merilu 1:5000. Na razgibanih območjih smo upoštevali petmetrske izohipse, na ravninskih pa tudi metrske, torej vse izohipse, ki jih je moč dobiti na omenjeni karti (Kamnik-47, Kamnik-48). Kjer so bile izohipse redke, smo dodali še nekaj vmesnih točk. Tako smo oblikovali vektorski sloj (zapis, karto) reliefa, ki smo jo nato rastrirali na kvadratke velikosti 5 krat $5 \mathrm{~m}$ oziroma $25 \mathrm{~m}^{2}$ (četrt ara) in tako dobili zelo natančen petmetrski digitalni model reliefa (DMR 5). Z DMR smo ugotovili naklone, višine, osončenost, ekspozicijo in druge reliefne razmere, hkrati pa predstavili trodimenzionalno (prostorsko) sliko reliefa arboretuma in okolice. Na podoben način smo oblikovali tudi sloje za ostale sestavine pokrajine.

Arboretum ima najmanjšo nadmorsko višino $335 \mathrm{~m}$ na najjužnejši točki arboretuma, najvišjo pa $399 \mathrm{~m}$ na vrhu Kopastega hriba. Pregled petmetrskih višinskih pasov pokaže, da je najpogostejši razred od 340 do $344 \mathrm{~m}$, saj pokriva kar $21 \%$ vseh površin arboretuma. Najbolj pogosta nadmorska višina je $355 \mathrm{~m} \quad(5,3 \%$ površin). Povprečna višina znaša $352 \mathrm{~m}$. Višinska razlika med najvišjo in najnižjo točko znaša $64 \mathrm{~m}$. Razgibana območja (Volčji in Kopasti hrib, Jamce, V hribih) imajo med vznožjem (dolino) in vrhom okrog $50 \mathrm{~m}$ višinske razlike, zato jih po geomorfoloških kriterijih lahko opredelimo kot gričevje, preostali del arboretuma pa je ravnina. Najmanjši naklon je $0^{\circ}$ in največji $46^{\circ}$. Najbolj pogost naklon je $1^{\circ}\left(35,5 \%\right.$ površin). Prevladujejo nakloni med 0 in $2^{\circ}$, kar pomeni raven svet. Takega sveta je $49 \%$. Povprečni naklon znaša $5,0^{\circ}$. Najbolj pogosta je jugozahodna ekspozicija, ki je značilna za $34 \%$ površin arboretuma. Sledi južna ekspozicija s $23 \%$ površin. Najmanj pogosti sta severna in severovzhodna ekspozicija, ki zavzemata komaj dobra $2 \%$ površin. Izrazito južne ekspozicije imajo južna pobočja Volčjega hriba in Kopastega hriba. Glede na predstavljene višinske in naklonske razmere lahko v grobem določimo pet reliefnih enot: gričevje Volčjega in Kopastega hriba s slemenoma v smeri severovzhod-jugozahod, dolinica Volčjega potoka $v$ podobni smeri na severozahodni strani gričevja, dolinica Hujskega potoka v podobni smeri na jugovzhodni strani gričevja, vršaj na južni strani gričevja in ravnina južno in jugozahodno od vršaja.

S prekrivanjem ostalih slojev naravnih sestavin pokrajine, ki so močno povezane in celo soodvisne, smo določili štiri geoekološke enote, za 
Preglednica 1: Višine, nakloni in ekspozicije $v$ Arboretumu Volčji potok.

\begin{tabular}{|c|c|c|c|c|c|c|c|c|}
\hline $\begin{array}{l}\text { Višinski pasovi } \\
\text { v metrih }\end{array}$ & Ari & Delež & $\begin{array}{l}\text { Naklonski ra } \\
\mathrm{v} \text { stopinjah }\end{array}$ & $\begin{array}{l}\text { Credi } \\
\text { Ari }\end{array}$ & Delež & Ekspozicija & Ari & Deleži \\
\hline $335,0-339,9$ & 1233 & 15,0 & $0,0-1,9$ & 4028 & 48,8 & Sever & 187 & 2,3 \\
\hline $340,0-344,9$ & 1727 & 20,9 & $2,0-5,9$ & 2275 & 27,6 & Severovzhod & 185 & 2,3 \\
\hline $345,0-349,9$ & 1320 & 16,0 & $6,0-11,9$ & 760 & 9,2 & Severozahod & 793 & 9,6 \\
\hline $350,0-354,9$ & 1382 & 16,8 & $12,0-19,9$ & 839 & 10,2 & Vzhod & 387 & 4,7 \\
\hline $355,0-359,9$ & 1148 & 13,9 & $20,0-29,9$ & 278 & 3,4 & Zahod & 712 & 8,6 \\
\hline $360,0-364,9$ & 314 & 3,8 & $30,0-44,9$ & 69 & 0,8 & Jugovzhod & 1314 & 15,9 \\
\hline $365,0-369,9$ & 175 & 2,1 & $45,0-89,9$ & 3 & 0,0 & Jugozahod & 2803 & 34,0 \\
\hline $370,0-374,9$ & 181 & 2,2 & & & & Jug & 1859 & 22,5 \\
\hline $375,0-379,9$ & 181 & 2,2 & & & & Neeksponirano & 12 & 0,1 \\
\hline $380,0-384,9$ & 200 & 2,4 & & & & & & \\
\hline $385,0-389,9$ & 152 & 1,8 & & & & & & \\
\hline $390,0-394,9$ & 152 & 1,8 & & & & & & \\
\hline $395,0-399,9$ & 87 & 1,1 & & & & & & \\
\hline Skupaj & 8252 & 100,0 & Skupaj & 8252 & 100,0 & Skupaj & 0202 & 100,0 \\
\hline
\end{tabular}

Slika 1: Višinski pasovi z mejo Arboretuma Volčji potok.

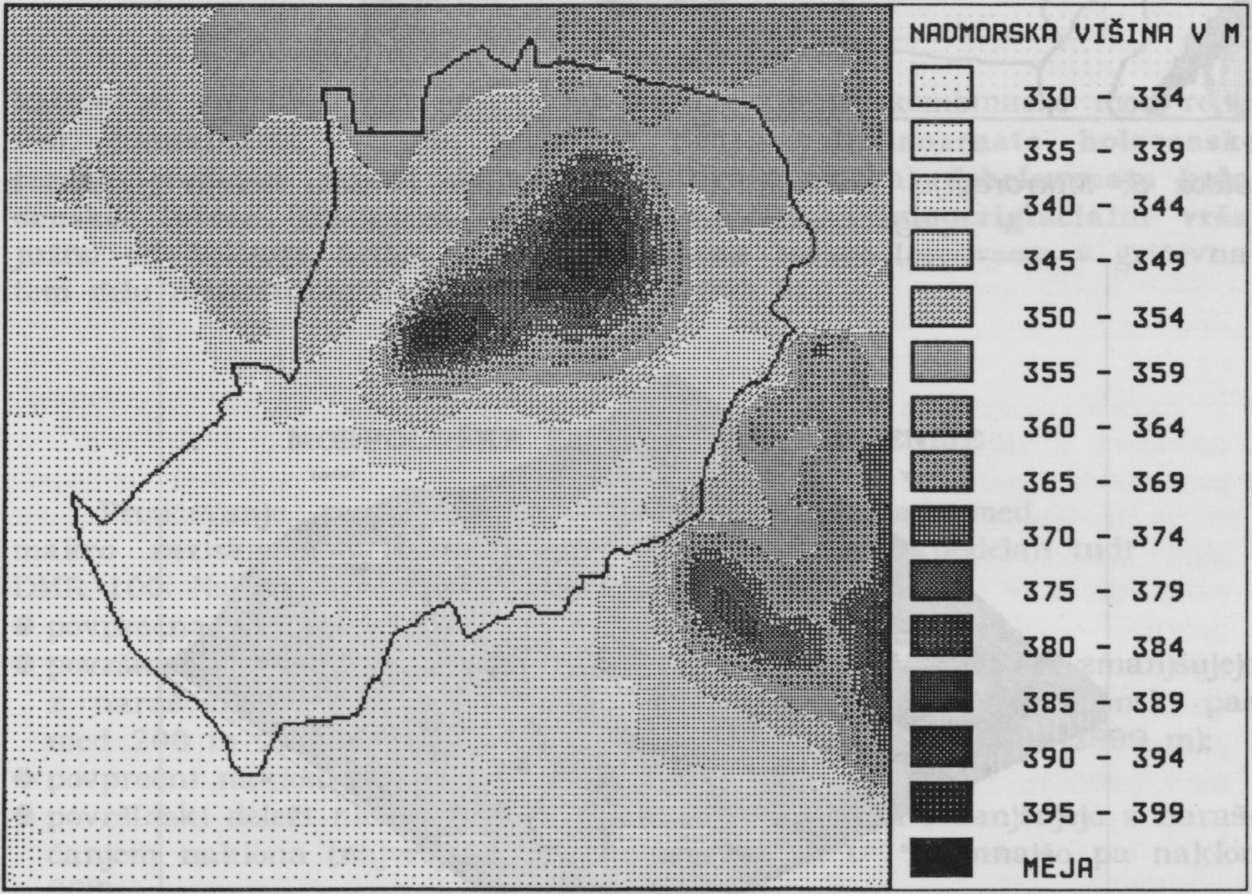


Slika 2: Naklonski razredi z rečno mrežo Arboretuma Volčji potok.

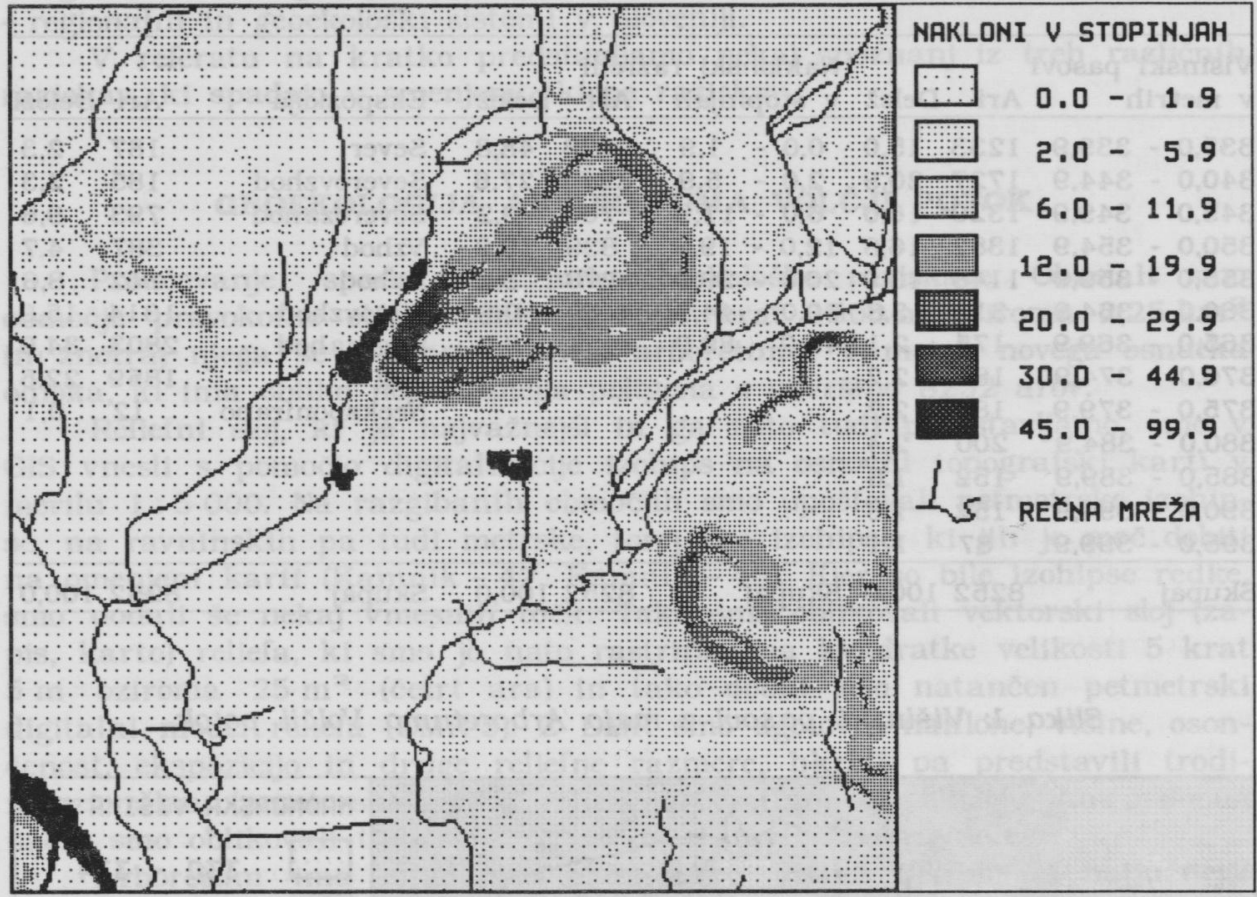

Slika 3: Mikroregije (pokrajinice) na digitalnem modelu reliefa (pogled $z$ jugozahoda, 45 stopinj nad obzorjem).

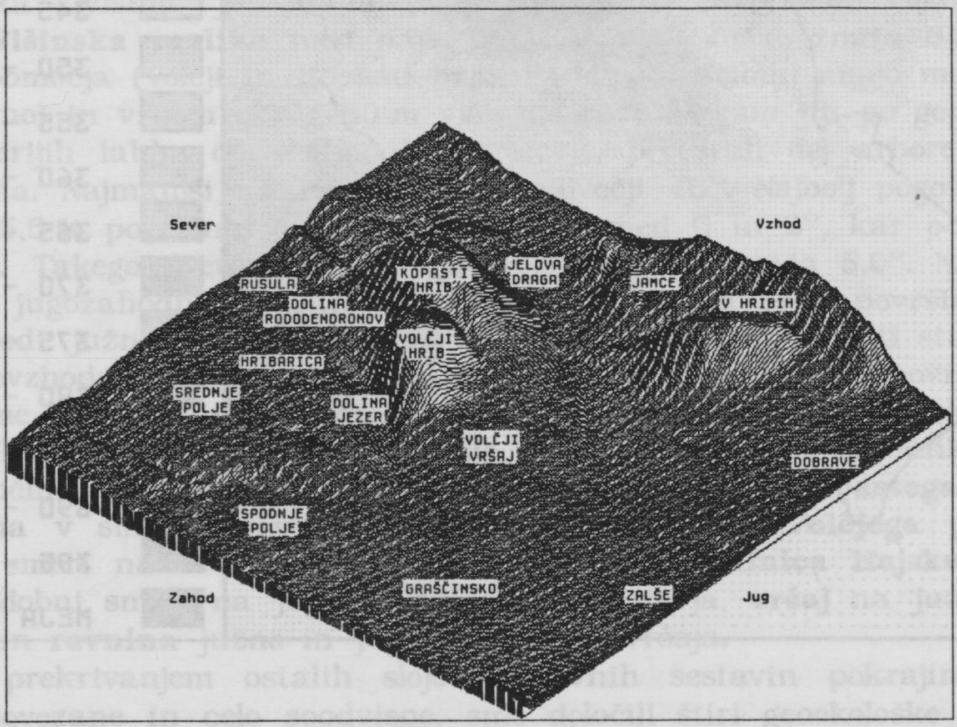


Slika 4: Digitalni model reliefa, kjer so nadmorske višine zamenjane $z$ nakloni, in prikazuje naklonsko razgibanost reliefa (pogled $\mathrm{z}$ jugozahoda).

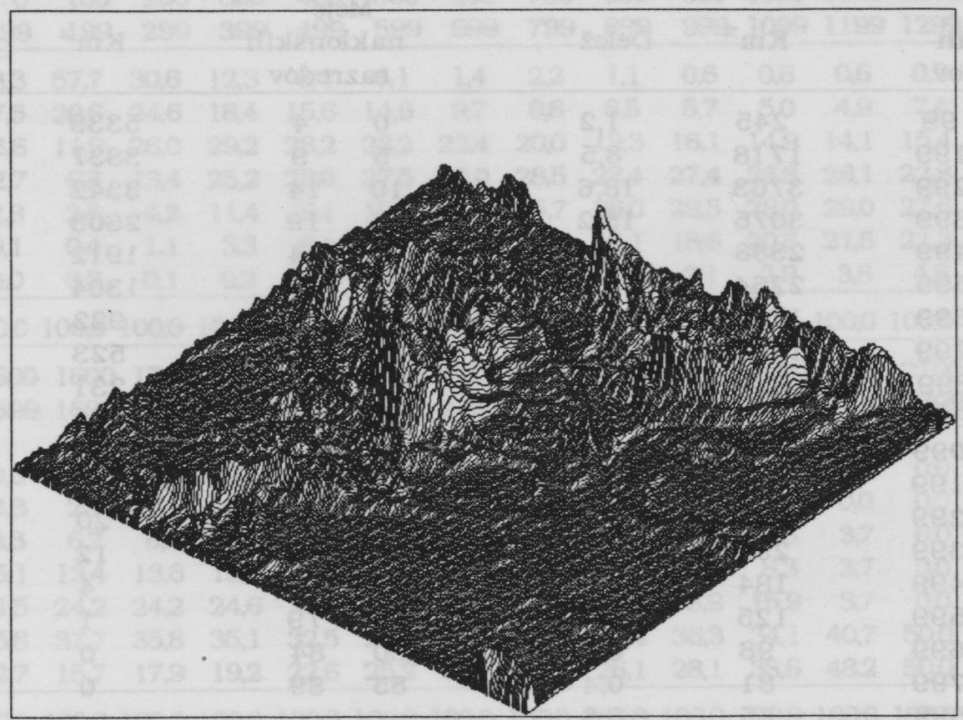

katere so značilne homogene, a svojstvene, tipične kombinacije med reliefom, kamninami, vodami, prstjo in rastjem: drobnozrnate holocenske terase (predvsem vzdolž Volčjega in Hujskega potoka), debelozrnate holocenske terase (predvsem na Spodnjem polju), fluvioperiglacialni vršaj južno od Volčjega hriba in konglomeratne terase (predvsem $v$ gričevnatem delu arboretuma in 'okolice), (Perko 1992 b).

\section{MORFOLOŠKE ZNAČILNOSTI SLOVENIJE}

Proučevanje morfoloških značilnosti Slovenije spada med makro raziskave. $\mathrm{V}$ njenem okviru smo med ostalim obdelali tudi DMR 100. Nekatere osnovne ugotovitve so:

- povprečna nadmorska višina Slovenije je $552,72 \mathrm{~m}$;

- površinski deleži stometrskih višinskih pasov se $\mathrm{v}$ splošnem zmanjšujejo z naraščanjem nadmorske višine (največjo površino ima višinski pas med 200 in 299 m, najmanjšo pa višinski pas med 2800 in 2899 m);

- povprečni naklon Slovenije znaša $13,17^{\circ}$;

- površinski deleži naklonskih razredov se $\mathrm{v}$ splošnem zmanjšujejo $\mathrm{z}$ naraščanjem naklona (največjo površino ima naklon $0^{\circ}$, najmnajšo pa naklon $\left.86^{\circ}\right)$;

- najmanjši povprečni hektarski naklon znaša $0^{\circ}$, največji pa $86^{\circ}$;

- z naraščanjem povprečne nadmorske višine narašča povprečni naklon; 
Preglednica 2: Pouršine in deleži pouršin višinskih in naklonskih razredov Slovenije na podlagi DMR 100.

\begin{tabular}{|c|c|c|c|c|c|c|c|}
\hline \multicolumn{2}{|c|}{$\begin{array}{c}\text { Meje } \\
\text { višinskih } \\
\text { razredov }\end{array}$} & \multirow{2}{*}{$\frac{\mathrm{Km}^{2}}{245}$} & \multirow{2}{*}{$\begin{array}{r}\text { Delež } \\
1,2\end{array}$} & \multicolumn{2}{|c|}{$\begin{array}{l}\text { Meje } \\
\text { naklonskih } \\
\text { razredov }\end{array}$} & \multirow{2}{*}{$\begin{array}{r}\mathrm{Km}^{2} \\
5339\end{array}$} & \multirow{2}{*}{$\begin{array}{c}\text { Delež } \\
26,4\end{array}$} \\
\hline 0 & 99 & & & 0 & 4 & & \\
\hline 100 & 199 & 1718 & 8,5 & 5 & 9 & 3837 & 18,9 \\
\hline 200 & 299 & 3763 & 18,6 & 10 & 14 & 3342 & 16,5 \\
\hline 300 & 399 & 3075 & 15,2 & 15 & 19 & 2603 & 12,9 \\
\hline 400 & 499 & 2388 & 11,8 & 20 & 24 & 1912 & 9,4 \\
\hline 500 & 599 & 2264 & 11,2 & 25 & 29 & 1304 & 6,4 \\
\hline 600 & 699 & 1717 & 8,5 & 30 & 34 & 922 & 4,5 \\
\hline 700 & 799 & 1308 & 6,5 & 35 & 39 & 523 & 2,6 \\
\hline 800 & 899 & 934 & 4,6 & 40 & 44 & 231 & 1,1 \\
\hline 900 & 999 & 640 & 3,2 & 45 & 49 & 113 & 0,6 \\
\hline 1000 & 1099 & 497 & 2,4 & 50 & 54 & 61 & 0,3 \\
\hline 1100 & 1199 & 410 & 2,0 & 55 & 59 & 32 & 0,2 \\
\hline 1200 & 1299 & 356 & 1,7 & 60 & 64 & 20 & 0,1 \\
\hline 1300 & 1399 & 259 & 1,3 & 65 & 69 & 12 & 0,1 \\
\hline 1400 & 1499 & 184 & 0,9 & 70 & 74 & 4 & 0,0 \\
\hline 1500 & 1599 & 125 & 0,6 & 75 & 79 & 1 & 0,0 \\
\hline 1600 & 1699 & 96 & 0,5 & 80 & 84 & 0 & 0,0 \\
\hline 1700 & 1799 & 81 & 0,4 & 85 & 89 & 0 & 0,0 \\
\hline 1800 & 1899 & 65 & 0,3 & & & & \\
\hline 1900 & 1999 & 46 & 0,2 & & & & \\
\hline 2000 & 2099 & 32 & 0,2 & B & & Sentlasns. & Oe 975\}B? \\
\hline 2100 & 2199 & 22 & 0,1 & mi clferis & ingr. & incusalat & 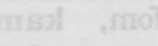 \\
\hline 2200 & 2299 & 16 & 0,1 & devingerst & act a & th natosybs & terbcosezes \\
\hline 2300 & 2399 & 10 & 0,0 & azas & 6020 & 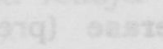 & 3 sulano: \\
\hline $\begin{array}{l}2400 \\
2500\end{array}$ & $\begin{array}{l}2499 \\
\text { in več }\end{array}$ & $\begin{array}{l}4 \\
1\end{array}$ & $\begin{array}{l}0,0 \\
0,0\end{array}$ & 20 & ari & 1) & bo ansu \\
\hline \multicolumn{2}{|c|}{ Skupaj } & 20256 & 100,0 & \multicolumn{2}{|c|}{ Skupaj } & 20256 & 100,0 \\
\hline
\end{tabular}

z naraščanjem stometrskih višinskih pasov narašča delež povprečnih naklonov $\mathrm{z}$ višjimi vrednostmi;

- povezanost povprečne nadmorske višine in povprečnega naklona je pozitivna in korelacijski koeficient znaša 0,1374 , kar je pri računanju korelacije iz več kot dva milijona podatkov izjemna vrednost, ki pri $99 \%$ zaupanju kar za 172-krat presega mejni koeficient statistične pomembnosti;

- največje nepravilnosti naraščanja povprečnega naklona po stometrskih višinskih pasovih so $\mathrm{v}$ pasu pod $100 \mathrm{~m}$, v pasu med 100 in $199 \mathrm{~m}$, v pasu med 1200 in $1299 \mathrm{~m}$ in $\mathrm{v}$ obeh stometrskih višinskih pasovih med 2200 in $2399 \mathrm{~m}$;

- podpovprečni naklon imajo le stometrski višinski pasovi med 0 in 399 $\mathrm{m}$;

- gostota površin posameznih naklonov kaže na največjo gostoto in koncentracijo največjih in najmanjših naklonov glede na posamezne višinske pasove; 
Preglednica 3: Naklonska sestava posameznih stometrskih višinskih pasov $v$ Sloveniji $v \%$.

\begin{tabular}{|c|c|c|c|c|c|c|c|c|c|c|c|c|c|c|c|}
\hline Sto- & 0 & 100 & 200 & 300 & 400 & 500 & 600 & 700 & $\begin{array}{l}800 \\
899\end{array}$ & $\begin{array}{l}900 \\
999\end{array}$ & 1000 & 100 & $\begin{array}{l}1200 \\
1299\end{array}$ & $\begin{array}{l}1300 \\
1399\end{array}$ & 1400 \\
\hline nye & & & & 99 & 95 & 9y & & & & & & & & & \\
\hline 0 & 3,3 & 77 & 6 & 123 & 8 & & & & & 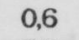 & 0 , & 8, & 0,9 & 0,6 & 0,3 \\
\hline 2- 5 & 27,5 & 20,6 & 24,6 & 18,4 & 15,6 & 14,9 & 9,7 & 9,8 & 8,5 & 5,7 & 5,0 & 4,9 & 7,4 & 2 & 3,9 \\
\hline $6-11$ & 23,6 & 11,9 & 26,0 & 29,2 & 23,2 & 23,2 & 22,4 & 20,0 & 19,3 & 16,1 & 14,9 & 14,1 & 15,4 & 12,5 & 11,7 \\
\hline $12-19$ & 12,7 & 6,8 & 13,4 & 25,2 & 28,0 & 27,5 & 31,0 & 28,5 & 28,4 & 27,4 & 26,8 & 26,1 & 22,8 & 21,9 & 19,0 \\
\hline $20-29$ & 2,8 & 2,6 & 4,2 & 11,4 & 18,1 & 19,6 & 24,1 & 25,7 & 26,0 & 29,5 & 29,0 & 29,0 & 27,6 & 27,8 & 25,8 \\
\hline $30-44$ & 0,1 & 0,4 & 1,1 & 3,3 & 6,4 & 8,2 & 10,8 & 12,9 & 15,1 & 18,6 & 20,8 & 21,5 & 21,3 & 26,1 & 30,7 \\
\hline $45-86$ & 0,0 & 0,0 & 0,1 & 0,2 & 0,3 & 0,5 & 0,6 & 0,9 & 1,6 & 2,1 & 2,9 & 3,8 & 4,6 & 5,9 & 8,6 \\
\hline
\end{tabular}

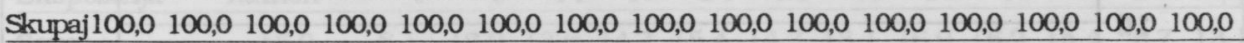

$\begin{array}{lllllllllllllllll}\text { Sto- } & 1500 & 1600 & 1700 & 1800 & 1900 & 2000 & 2100 & 2200 & 2300 & 2400 & 2500 & 2600 & 2700 & 2800\end{array}$

pinje 1599169917991899199920992199229023992499259926992799 2899Skupaj

$\begin{array}{llllllllllllllll}0-1 & 0,3 & 0,2 & 0,2 & 0,3 & 0,2 & 0,1 & 0,0 & 0,1 & 0,2 & 0,2 & 0,0 & 0,0 & 0,0 & 0,0 & 14,9\end{array}$

$\begin{array}{llllllllllllllll}2-5 & 3,3 & 2,1 & 2,1 & 1,4 & 1,3 & 1,9 & 0,7 & 1,0 & 1,7 & 1,0 & 0,8 & 0,0 & 0,0 & 0,0 & 15,5\end{array}$

$\begin{array}{llllllllllllllll}6-11 & 8,3 & 6,7 & 6,2 & 5,7 & 5,0 & 5,7 & 3,2 & 2,8 & 5,3 & 3,5 & 2,3 & 3,7 & 0,0 & 0,0 & 21,8\end{array}$

$\begin{array}{llllllllllllllll}12-19 & 15,1 & 13,4 & 13,6 & 13,7 & 13,9 & 14,5 & 10,5 & 11,8 & 13,4 & 12,0 & 8,3 & 3,7 & 0,0 & 0,0 & 22,4\end{array}$

$\begin{array}{llllllllllllllll}20-29 & 24,5 & 24,2 & 24,2 & 24,6 & 24,5 & 23,3 & 20,3 & 19,4 & 18,9 & 18,9 & 15,9 & 3,7 & 0,0 & 0,0 & 15,9\end{array}$

$\begin{array}{llllllllllllllll}30-44 & 35,8 & 37,7 & 35,8 & 35,1 & 32,5 & 29,3 & 35,0 & 33,8 & 34,4 & 36,3 & 34,1 & 40,7 & 50,0 & 0,0 & 8,3\end{array}$

\begin{tabular}{llllllllllllllll}
$45-86$ & 12,7 & 15,7 & 17,9 & 19,2 & 22,6 & 25,2 & 30,3 & 31,1 & 26,1 & 28,1 & 38,6 & 48,2 & 50,0 & 100,0 & 1,2 \\
\hline
\end{tabular}

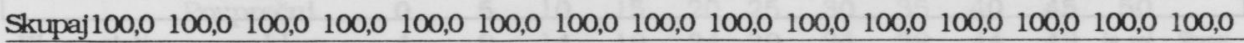

Slika 5: Pogostostna razporeditev pouprečnih hektarskih nadmorskih višin $v \%$ po stometrskih pasovih $v$ Sloveniji.

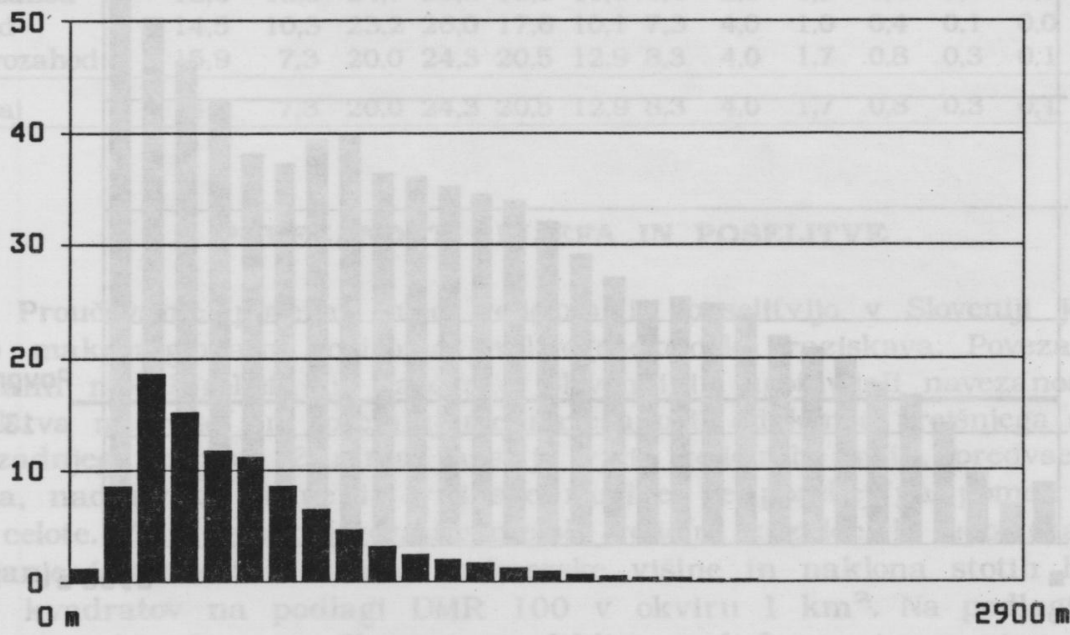


Slika 6: Pogostostna razporeditev povprečnih hektarskih naklonov v \% po stopinjah $v$ Sloveniji.

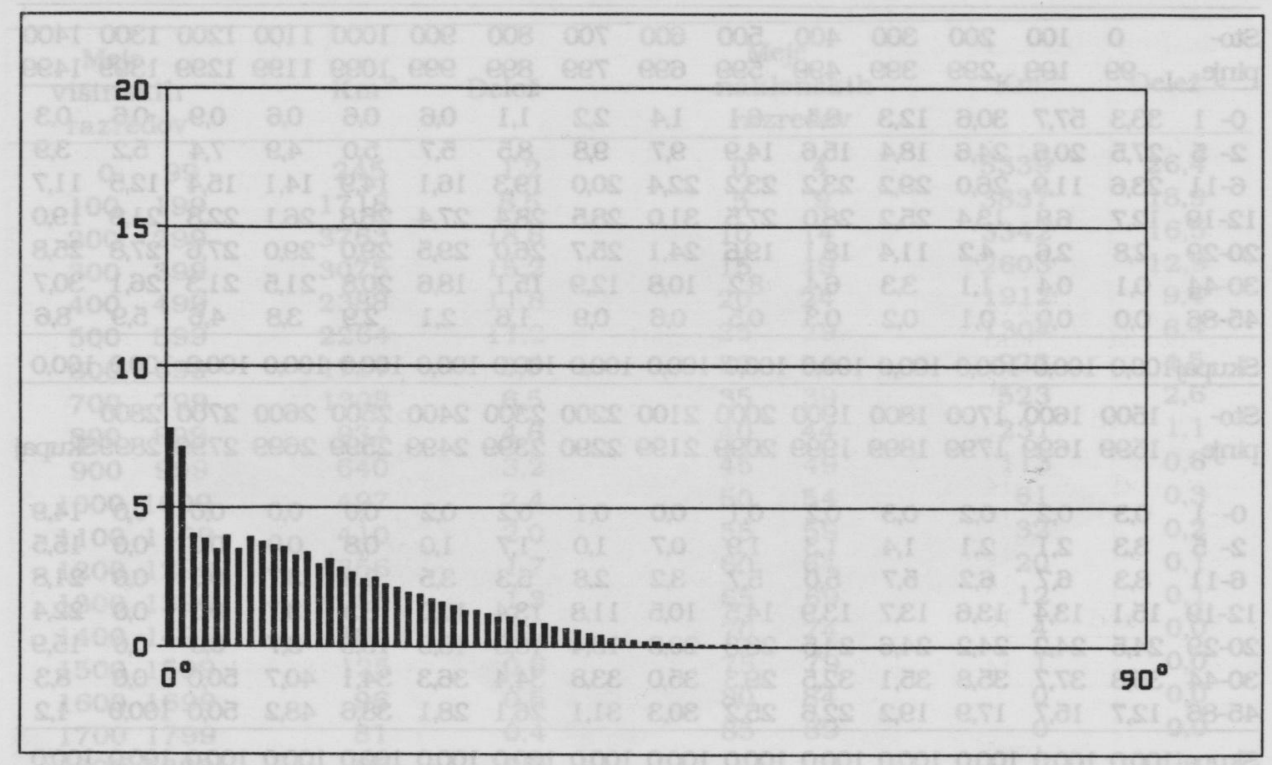

Slika 7: Povprečni nakloni stometrskih višinskih pasov v Sloveniji.

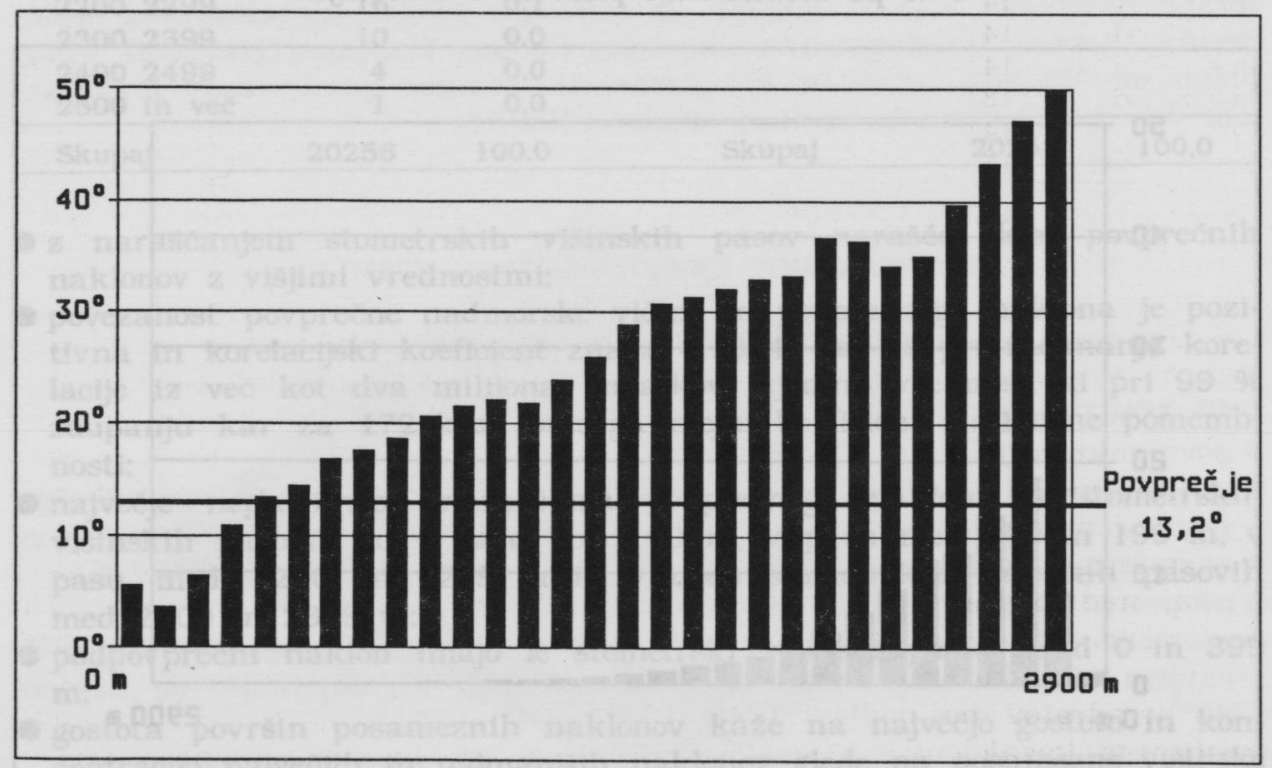


največjo gostoto ima naklon $0^{\circ}$, saj znaša $v$ povprečju $7,8 \mathrm{ha} / \mathrm{km}^{2}, \mathrm{v}$ pasu med 100 in $199 \mathrm{~m}$, kjer leži skoraj polovica vseh hektarskih kvadratov s tem naklonom, pa kar $37 \mathrm{ha} / \mathrm{km}^{2}$;

- najpogostejši povprečni hektarski naklon je $0^{\circ}$ in je značilen za $8 \%$ Slovenije in podobno (Perko 1992 a);

Preglednica 4: Nakloni glede na ekspozicijo iznad ravnega sueta $v$ Sloveniji.

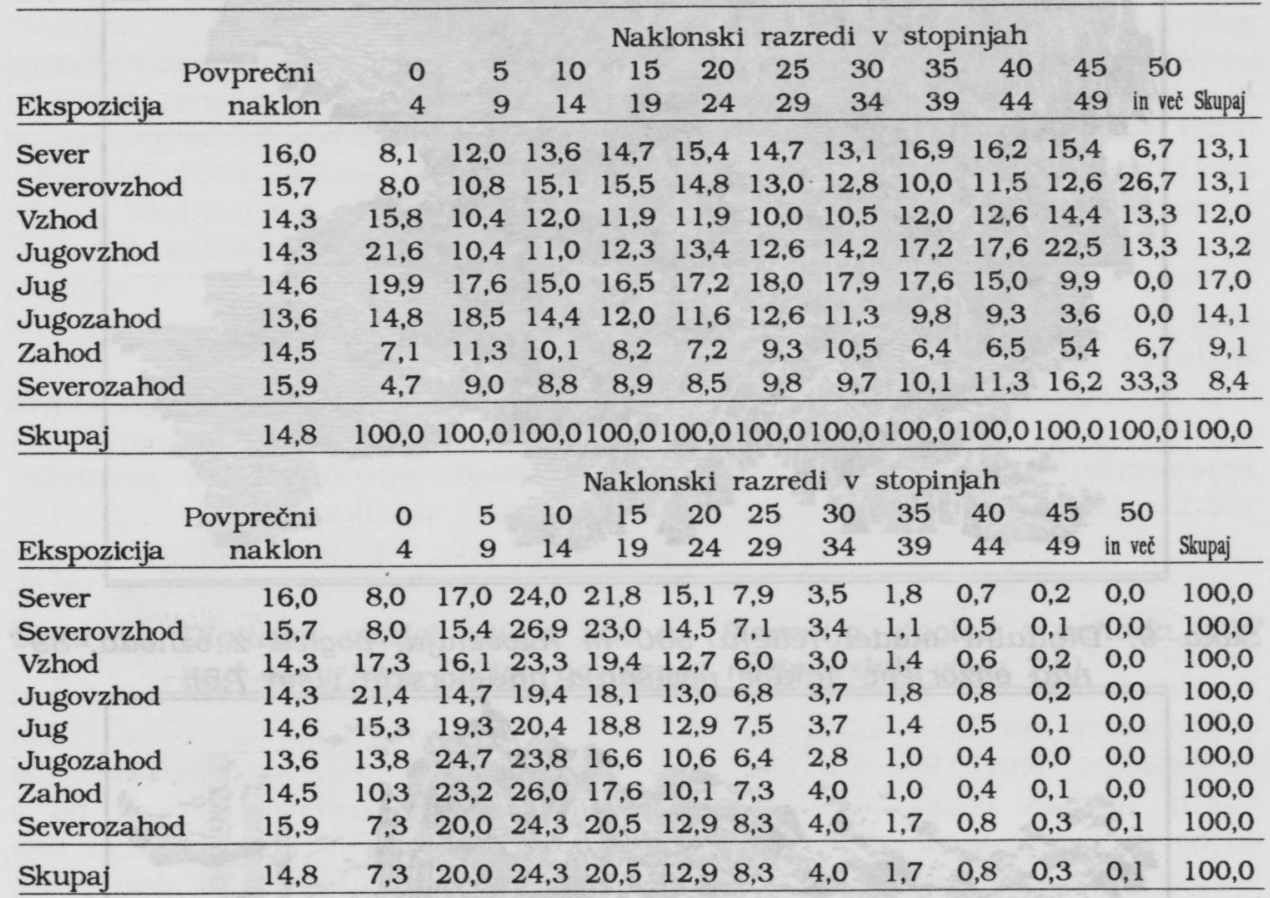

POVEZANOST RELIEFA IN POSELITVE

Proučevanje povezav med reliefom in poselitvijo $v$ Sloveniji je prav tako makroregionalna oziroma makrogeoekološka raziskava. Povezali smo digitalni model reliefa in naselja $v$ Sloveniji in ugotavljali navezanost prebivalstva na relief in spreminjanje navezanosti od konca prejšnjega stoletja do zadnjega popisa. Zanimal nas je vpliv reliefnih prvin, predvsem naklona, nadmorske višine in višinske razlike, še posebej pa pomen reliefa kot celote. Zato smo oblikovali sintetski reliefni kazalec, ki upošteva spreminjanje (standardni odklon) nadmorske višine in naklona stotih hektarskih kvadratov na podlagi DMR $100 \mathrm{v}$ okviru $1 \mathrm{~km}^{2}$. Na podlagi vrednosti tega kazalca smo Slovenijo razdelili na reliefne enote: ravnino, gričevje, hribovje in gorovje in ta sloj, podobno kot smo to storili pri reliefnih 
Slika 8: Digitalni model reliefa $500 \mathrm{~m}$ (Slovenija, pogled $\mathrm{z}$ juga, $89^{\circ}$ nad obzorjem, faktor povišanja nadmorskih višin 7,5).

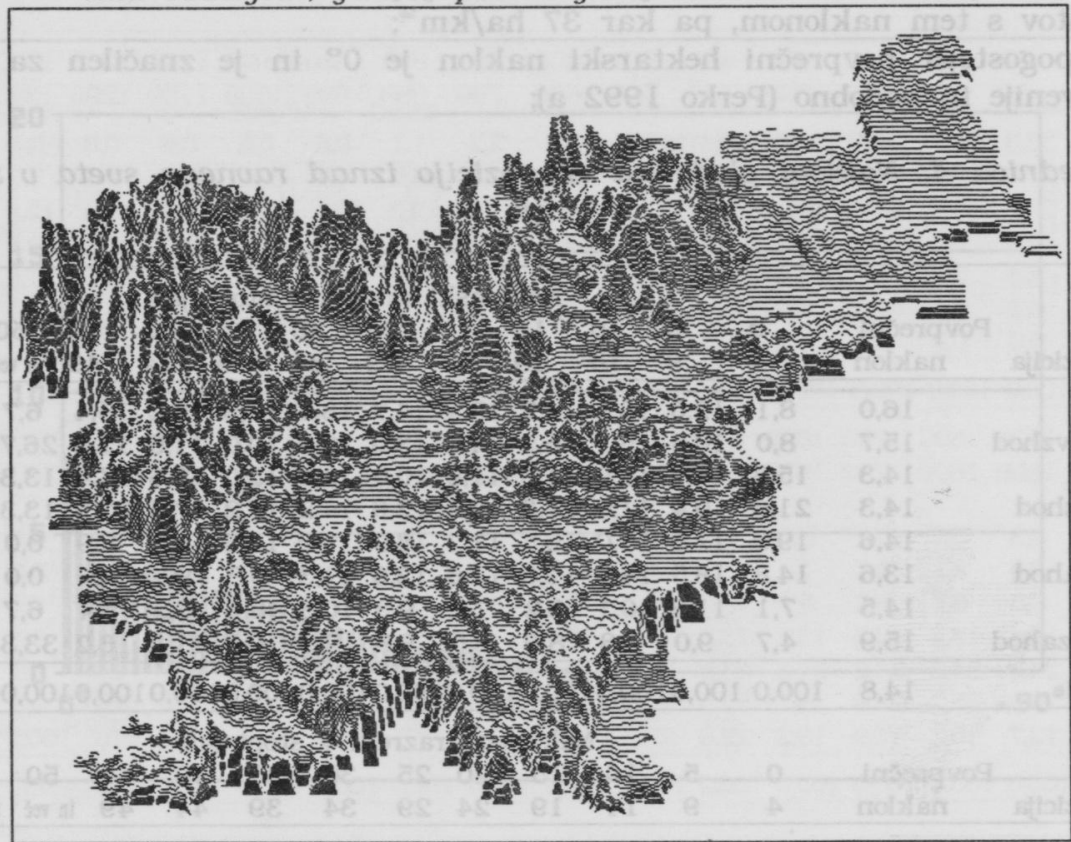

Slika 9: Digitalni model reliefa $500 \mathrm{~m}$ (Slovenija, pogled z vzhoda, $89^{\circ}$ nad obzorjem, faktor povišanja nadmorskih višin 7,5 ).

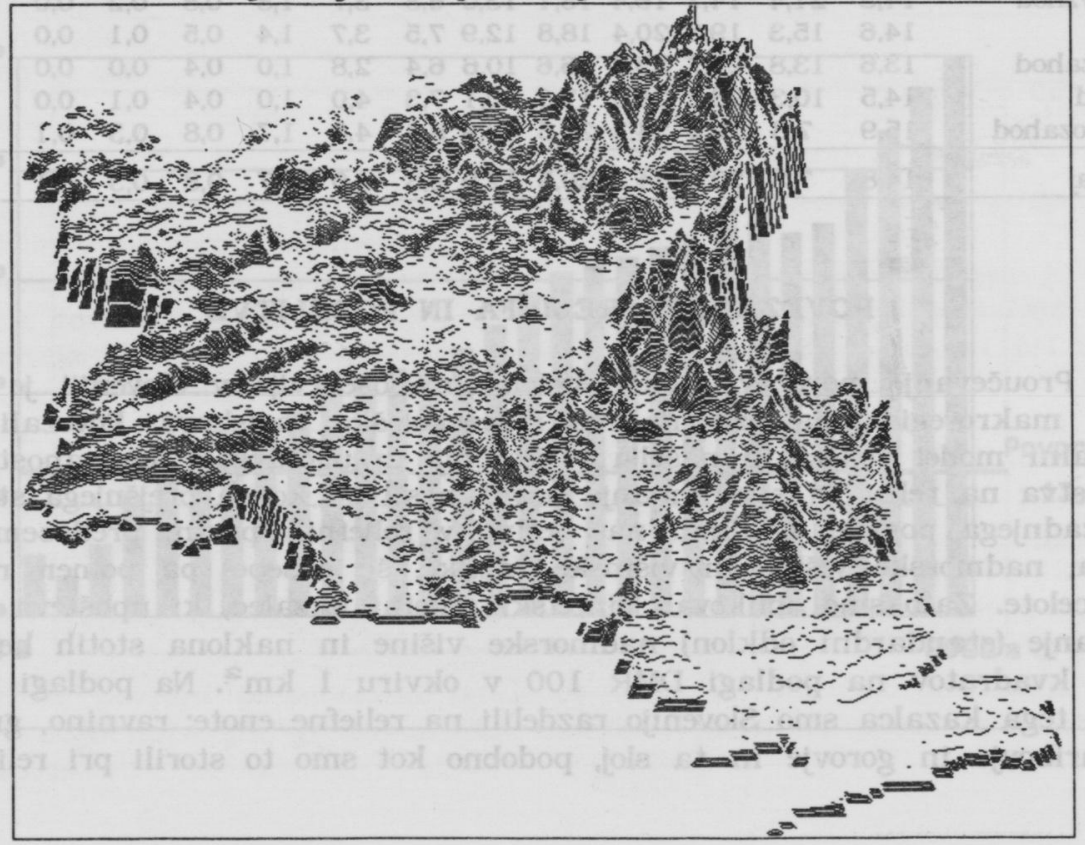


Slika 10: Digitalni model reliefa $500 \mathrm{~m}$ (Slovenija, pogled s severa, 89 ${ }^{\circ}$ nad obzorjem, faktor povišanja nadmorskih višin 7,5).

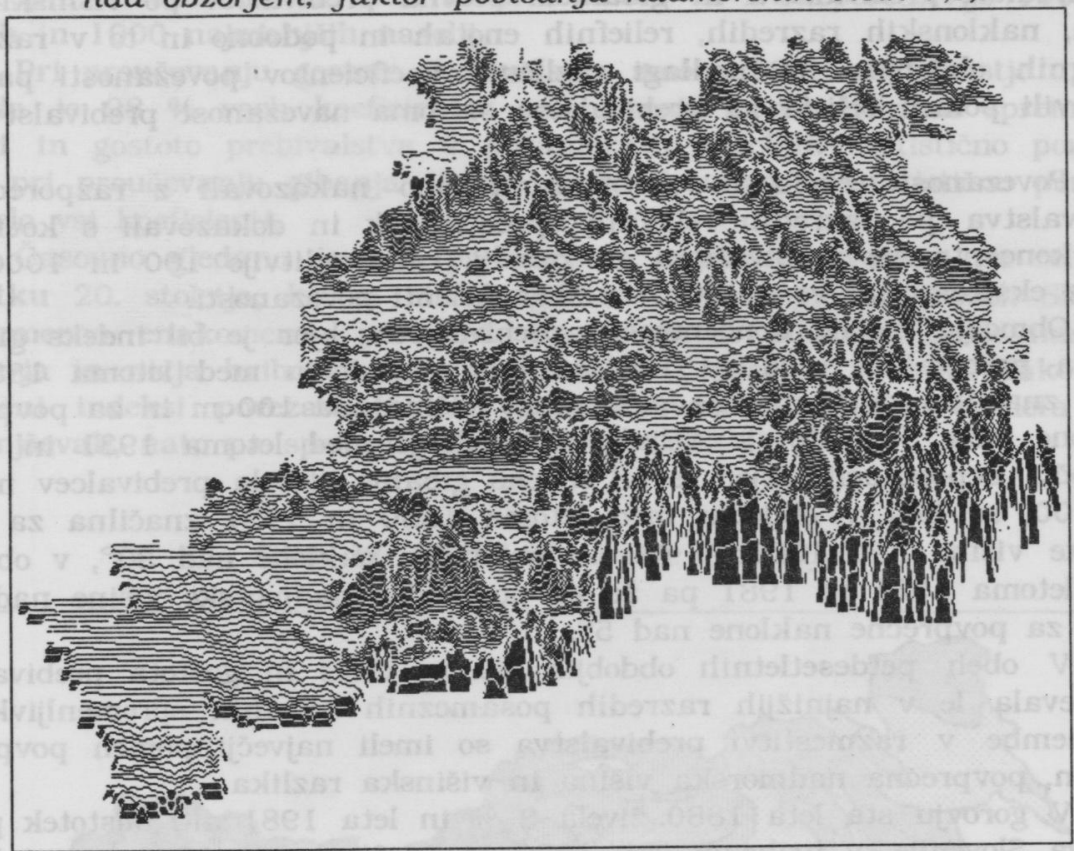

Slika 11: Digitalni model reliefa $500 \mathrm{~m}$ (Slovenija, pogled z zahoda, $89^{\circ}$ nad obzorjem, faktor povišanja nadmorskih višin 7,5 ).

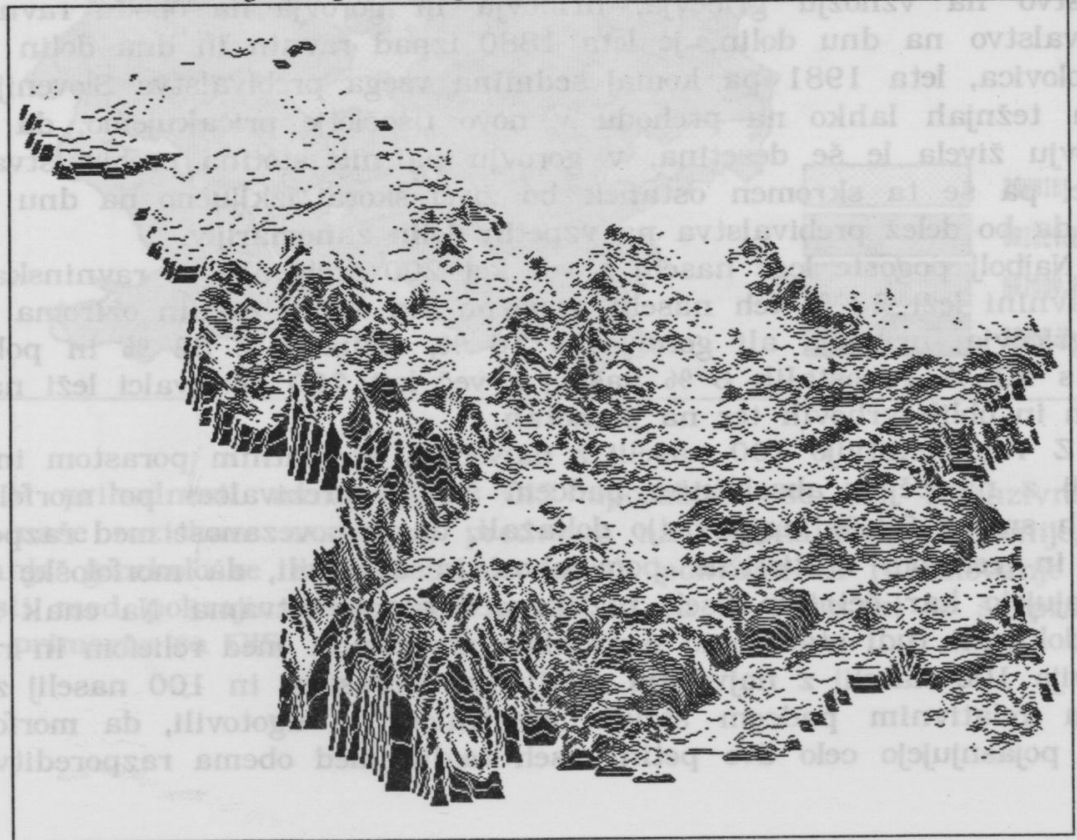


prvinah, prekrili s prebivalstvenimi sloji. Tako smo ugotovili razlike $\mathrm{v}$ razporeditvi prebivalstva in gibanjem števila prebivalcev po višinskih pasovih, naklonskih razredih, reliefnih enotah in podobno in to $\mathrm{v}$ različnih časovnih obdobjih, na podlagi različnih koeficientov povezanosti pa smo ugotovili pomen reliefa za prebivalstvo oziroma navezanost prebivalstva na relief.

Povezanost reliefa in prebivalstva smo nakazovali $z$ razporeditvijo prebivalstva po razredih reliefnih spremenljivk in dokazovali s koeficientom koncentracije prebivalstva in naselij, razporeditvijo 100 in 1000 naselij $\mathrm{z}$ ekstremnimi vrednostmi in s koeficienti povezanosti.

Območja močne koncentracije prebivalstva, kjer je bil indeks gibanja števila prebivalcev večji od 120 , so bila $v$ obdobju med letoma 1880 in 1931 značilna za povprečne nadmorske višine pod $100 \mathrm{~m}$ in za povprečne naklone pod $5^{\circ}$. Isto je veljalo za obdobje med letoma 1931 in 1981. Območja depopulacije, kjer je bil indeks gibanja števila prebivalcev manjši od 100, so bila $v$ obdobju med letoma 1880 in 1931 značilna za nadmorske višine nad $1000 \mathrm{~m}$ in za povprečne naklone nad $30^{\circ}, \mathrm{v}$ obdobju med letoma 1931 in 1981 pa že za povprečne nadmorske višine nad 500 $\mathrm{m}$ in za povprečne naklone nad $5^{\circ}$.

$\mathrm{V}$ obeh petdesetletnih obdobjih sta se delež in gostota prebivalstva povečevala le $\mathrm{v}$ najnižjih razredih posameznih reliefnih spremenljivk. Za spremembe $v$ razmestitvi prebivalstva so imeli največji pomen povprečni naklon, povprečna nadmorska višina in višinska razlika.

V gorovju sta leta 1880 živela $2 \%$ in leta 1981 niti odstotek prebivalstva Slovenije, v hribovju leta 1880 še $26 \%$ in leta 1981 komaj $18 \%$, v gričevju leta 1880 dobrih $51 \%$ in leta 1981 le še slabih $40 \%$, na ravnini pa leta 1880 komaj $21 \%$ in leta 1981 že $40 \%$. Če izločimo prebivalstvo na vznožju gričevja, hribovja in gorovja na obodu ravnin in prebivalstvo na dnu dolin, je leta 1880 iznad ravnin in dna dolin živela še polovica, leta 1981 pa komaj sedmina vsega prebivalstva Slovenije. Ob takih težnjah lahko na prehodu $\mathrm{v}$ novo tisočletje pričakujemo, da bo $\mathrm{v}$ hribovju živela le še desetina, v gorovju pa niti stotina prebivalstva Slovenije, pa še ta skromen ostanek bo živel skoraj izključno na dnu dolin, tako da bo delež prebivalstva na vzpetih delih zanemarljiv.

Najbolj pogoste lege naselij $z$ več kot 200 prebivalci so ravninska, ker na ravnini leži $23 \%$ teh naselij, vznožna (na obodu ravnin oziroma vznožju gričevja, hribovja ali gorovja) s $16 \%$, dolinska $z 32 \%$ in pobočna lega s $23 \%$. Preostalih $6 \%$ naselij z več kot 200 prebivalci leži na slemenih in oblih vrhovih ter na planotah.

$Z$ razporeditvijo 100 naselij $z$ največjim absolutnim porastom in 100 naselij $z$ največjim absolutnim padcem števila prebivalcev po morfoloških enotah smo z $99 \%$ verjetnostjo dokazali, da je povezanost med razporeditvijo in reliefom statistično pomembna in ugotovili, da morfološke enote pojasnjujejo kar četrtino vseh razlik med razporeditvama. Na enak način smo dokazali tudi statistično pomembno povezanost med reliefom in razporeditvijo 100 naselij $z$ največjim relativnim porastom in 100 naselij $z$ največjim relativnim padcem števila prebivalcev in ugotovili, da morfološke enote pojasnjujejo celo dve petini vseh razlik med obema razporeditvama. 
Isto lahko dokažemo tudi $\mathrm{z}$ razporeditvijo 1000 naselij $\mathrm{z}$ najmanjšim in največjim indeksom rasti števila prebivalcev in $z$ razporeditvijo 1000 največjih in 1000 najmanjših naselij.

Pri proučevanju gostote prebivalstva smo z 99 \% verjetnostjo ugotovili, da je $98 \%$ vseh koeficientov povezanosti med reliefnimi spremenljivkami in gostoto prebivalstva $\mathrm{v}$ posameznih obdobjih statistično pomembnih, pri proučevanju gibanja števila prebivalcev pa so statistično pomembni celo vsi koeficienti.

Časovno gledano je bilo prebivalstvo najmanj navezano na relief na začetku 20. stoletja, ko so bili razgibani in nerazgibani predeli Slovenije sorazmerno enakomerno poseljeni. Pred tem so bila bolj gosto naseljena gričevja in nižja hribovja (inverzna poselitev), zdaj pa ravnine. Tako so se različni indeksi povezanosti med prebivalstvom in reliefom do leta 1931 zmanjševali, nato pa spet naraščali (Perko 1992 c).

Slika 12: Morfološke enote Slovenije.

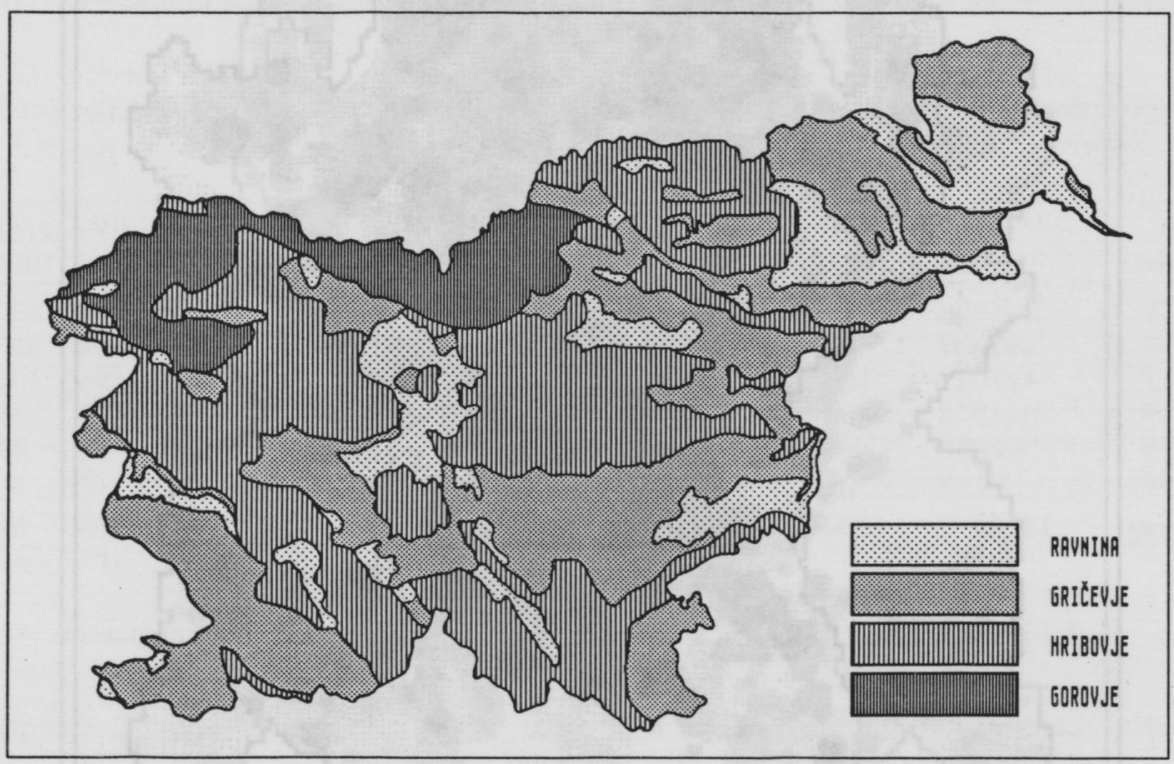

V prihodnosti nameravamo GIS uporabljati še bolj intenzivno, saj bodo naše raziskave usmerjene predvsem na regionalizacijo Slovenije, ugotavljanje geoekološke ranljivosti slovenskih pokrajin in raziskovanje povezanosti med pokrajinskimi sestavinami, to pa so teme, ki so še prav posebej primerne za GIS. 
Slika 13: Gibanje števila prebivalcev v Sloveniji med letoma 1931 in 1991.

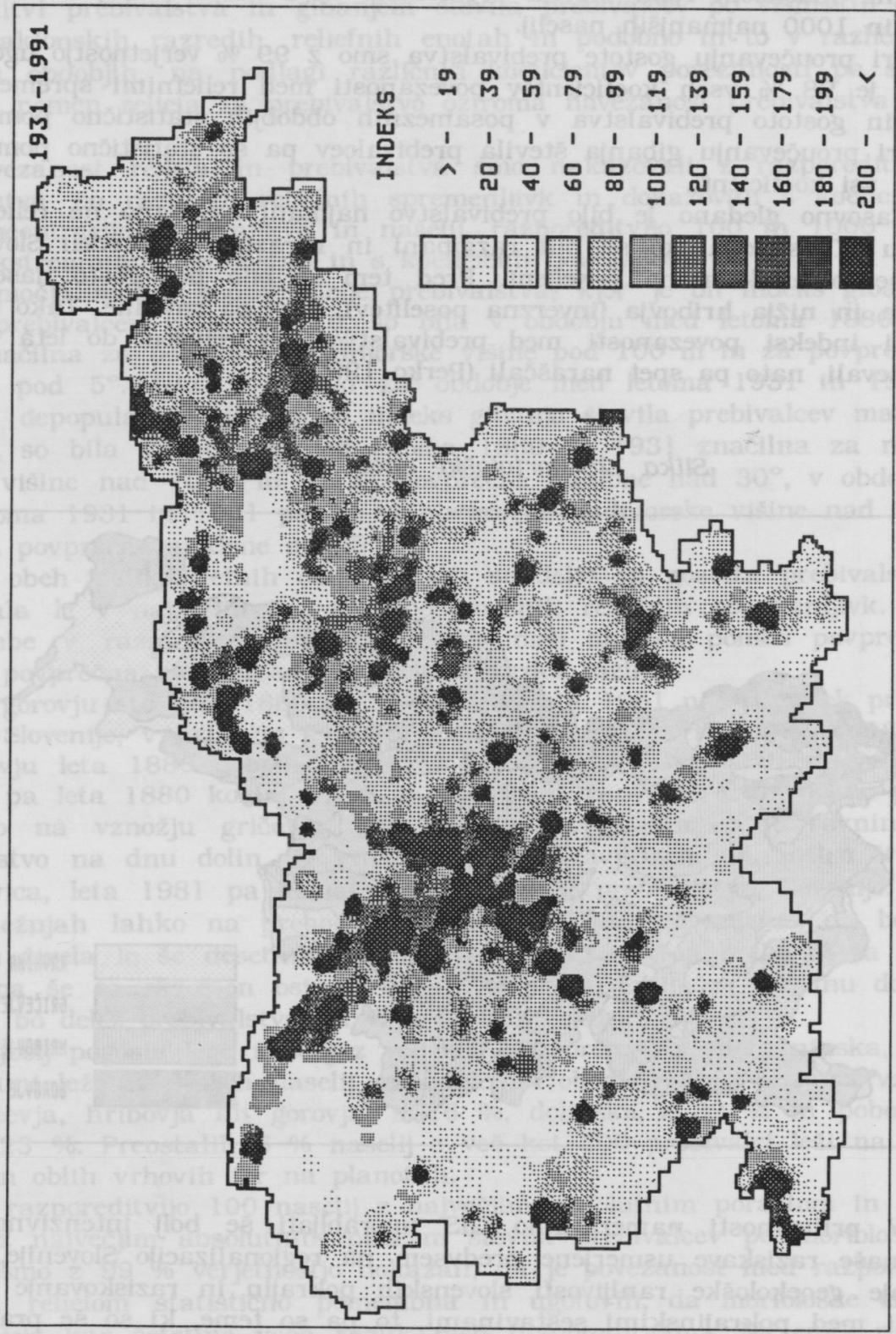


Slika 14: Gostota prebivalstua v Sloveniji leta 1991.

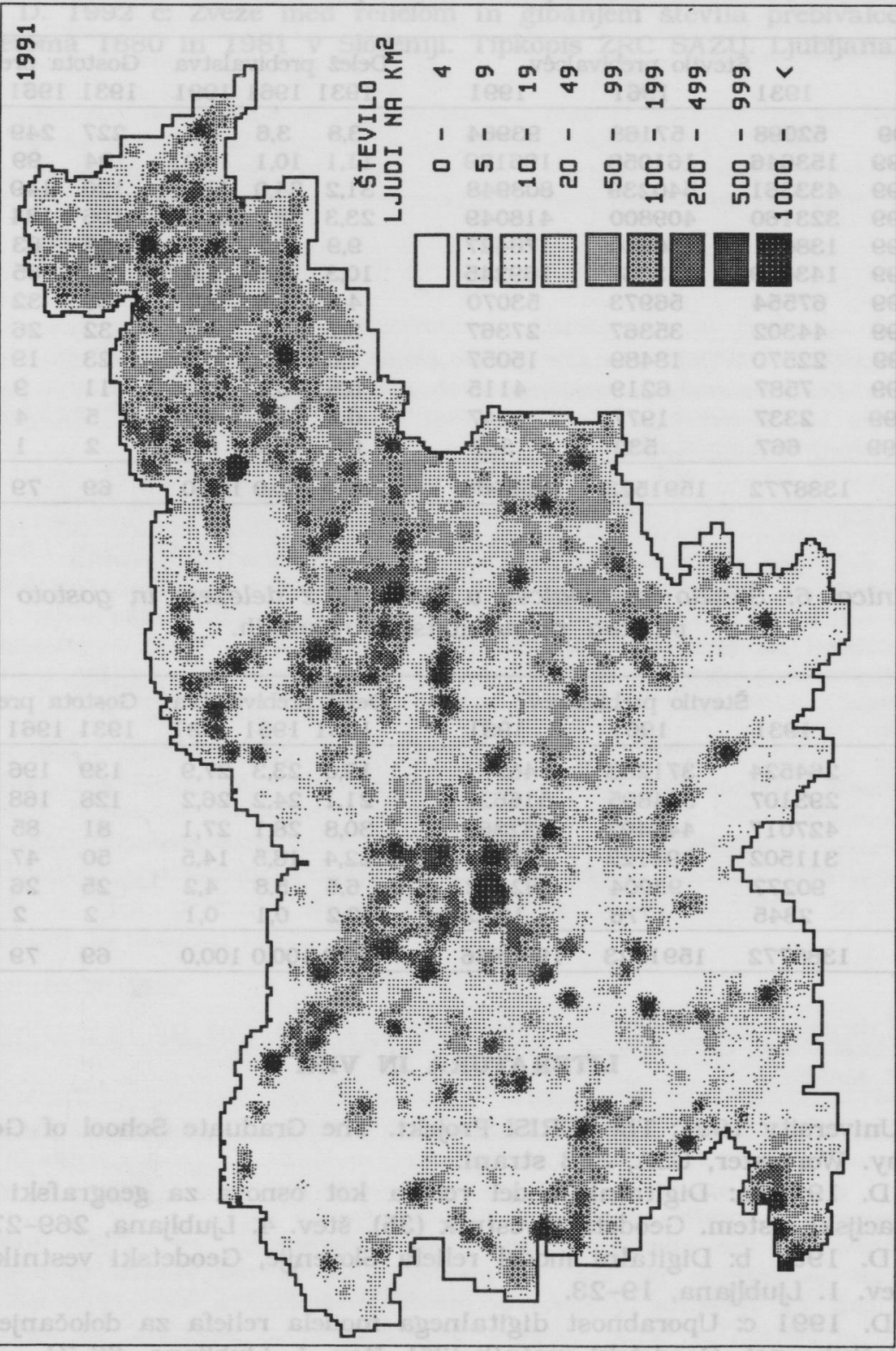


Preglednica 5: Število prebivalcev $v$ Sloveniji $z$ deležem in gostoto prebivalstua po višinskih pasovih.

\begin{tabular}{|c|c|c|c|c|c|c|c|c|c|}
\hline \multirow{2}{*}{$\begin{array}{l}\text { Meji } \\
\text { razreda }\end{array}$} & \multicolumn{3}{|c|}{ Število prebivalcev } & \multicolumn{3}{|c|}{ Delež prebivalstva } & \multicolumn{3}{|c|}{ Gostota prebivalst. } \\
\hline & 1931 & 1961 & 1991 & 1931 & 1961 & 1991 & 1931 & 1961 & 199 \\
\hline 0- 99 & 52098 & 57168 & 93964 & 3,8 & 3,6 & 4,8 & 227 & 249 & 409 \\
\hline $100-199$ & 153646 & 161058 & 196129 & 11,1 & 10,1 & 10,0 & 94 & 99 & 121 \\
\hline 200- 299 & 433361 & 540239 & 808948 & 31,2 & 34,0 & 41,1 & 120 & 149 & 224 \\
\hline $300-399$ & 323160 & 409800 & 418049 & 23,3 & 25,7 & 21,3 & 106 & 134 & 137 \\
\hline $400-499$ & 138071 & 150640 & 178427 & 9,9 & 9,5 & 9,1 & 58 & 63 & 74 \\
\hline $500-599$ & 143419 & 153061 & 169245 & 10,3 & 9,6 & 8,6 & 61 & 65 & 72 \\
\hline $600-699$ & 67554 & 56973 & 53070 & 4,9 & 3,6 & 2,7 & 38 & 32 & 30 \\
\hline $700-799$ & 44302 & 35367 & 27367 & 3,2 & 2,2 & 1,4 & 32 & 26 & 20 \\
\hline $800-899$ & 22570 & 18489 & 15057 & 1,6 & 1,2 & 0,8 & 23 & 19 & 16 \\
\hline $900-999$ & 7587 & 6219 & 4115 & 0,5 & 0,4 & 0,2 & 11 & 9 & 6 \\
\hline $1000-1099$ & 2337 & 1977 & 1247 & 0,2 & 0,1 & 0,0 & 5 & 4 & 2 \\
\hline $1100-1199$ & 667 & 532 & 368 & 0,0 & 0,0 & 0,0 & 2 & 1 & 1 \\
\hline Skupaj & 8772 & 1591523 & 986 & 00,0 & 00,0 & 00,0 & 69 & 79 & 97 \\
\hline
\end{tabular}

Preglednica 6: Število prebivalcev $v$ Sloveniji $z$ deležem in gostoto prebivalstua po naklonskih razredih.

\begin{tabular}{lrrrrrrrrr}
\hline Meji & \multicolumn{3}{c}{ Število prebivalcev } & \multicolumn{3}{c}{ Delež prebivalstva } & \multicolumn{2}{c}{ Gostota prebivalstva } \\
razreda & 1931 & 1961 & 1991 & 1931 & 1961 & 1991 & 1931 & 1961 & 1991 \\
\hline $0-1$ & 264524 & 371233 & 548571 & 19,0 & 23,3 & 27,9 & 139 & 196 & 289 \\
$2-5$ & 293107 & 384895 & 516620 & 21,1 & 24,2 & 26,2 & 128 & 168 & 226 \\
$6-11$ & 427017 & 446492 & 532369 & 30,8 & 28,1 & 27,1 & 81 & 85 & 101 \\
$12-19$ & 311502 & 294123 & 285004 & 22,4 & 18,5 & 14,5 & 50 & 47 & 46 \\
$20-29$ & 90277 & 93004 & 82412 & 6,5 & 5,8 & 4,2 & 25 & 26 & 23 \\
$30-44$ & 2345 & 1776 & 1010 & 0,2 & 0,1 & 0,1 & 2 & 2 & 1 \\
\hline Skupaj & 1388772 & 1591523 & 1965986 & 100,0 & 100,0 & 100,0 & 69 & 79 & 97 \\
\hline
\end{tabular}

\section{LITERATURA IN VIRI}

Clark University 1991: The IDRISI Projekt. The Graduate School of Geography. Worcester, USA, 363 strani.

Perko, D. 1991 a: Digitalni model reliefa kot osnova za geografski informacijski sistem. Geodetski vestnik (35), štev. 4. Ljubljana, 269-274.

Perko, D. 1991 b: Digitalni model reliefa Slovenije, Geodetski vestnik (38), štev. 1. Ljubljana, 19-23.

Perko, D. 1991 c: Uporabnost digitalnega modela reliefa za določanje morfoloških enot, Geodetski vestnik (35), štev. 1. Ljubljana, 66-71.

Perko, D., 1992 a: Nakloni v Sloveniji in digitalni model reliefa, Geodetski vestnik (36), štev. 2. Ljubljana, 115-121. 
Perko, D. 1992 b: Geoekologija Arboretuma Volčji potok. Tipkopis na ZRC SAZU. Ljubljana.

Perko, D. 1992 c: Zveze med reliefom in gibanjem števila prebivalcev med letoma 1880 in 1981 v Sloveniji. Tipkopis ZRC SAZU. Ljubljana. 